\title{
Geologic Map of Los Humeros volcanic complex and geothermal field, eastern Trans-Mexican Volcanic Belt
}

\section{Mapa geológico del complejo volcánico Los Humeros y campo geotérmico, sector oriental del Cinturón Volcánico Trans-Mexicano}

\author{
Gerardo Carrasco-Núñez*a , Javier Hernández ${ }^{\mathrm{a}}$, Lorena De León ${ }^{\mathrm{a}}$, Pablo Dávilab ${ }^{\mathrm{b}}$, Gianluca Norinic ${ }^{\mathrm{c}}$, Juan Pablo Bernal ${ }^{\mathrm{a}}$, \\ Brian Jicha $^{\mathrm{d}}$, Mario Navarro ${ }^{\mathrm{a}}$, Penélope López-Quiroz ${ }^{\mathrm{a}}$ \\ ${ }^{a}$ Centro de Geociencias, Universidad Nacional Autónoma de México, Campus UNAM Juriquilla, Queretaro, 76230, Mexico \\ ${ }^{b}$ Instituto Potosino de Investigación Científica y Tecnológica, (IPICYT), San Luis Potosi, SLP, 78216, Mexico \\ ${ }^{c}$ Istituto per la Dinamica dei Processi Ambientali, CNR, 20125, Milano, Italy \\ ${ }^{d}$ University of Wisconsin-Madison, Madison, WI, 53706, USA
}

\begin{abstract}
We present an updated version of the geologic map of Los Humeros Volcanic Complex (LHVC) and geothermal field, based on a complete revised characterization of the rock units and contacts, structural features, stratigraphy and recent radiometric dating with modern methods (U/Th, 40Ar/39Ar, Carrasco-Núñez et al., 2017, in press), together with the use of high resolution Digital Terrain Model at $1 \mathrm{~m}$ resolution and Google Earth optical imagery. Improvements of this version include refined stratigraphic sequence, revised classification of each lithostratigraphic unit, updated structural features and geochronologic data; all together providing constraints to support a new evolutionary volcanic history for LHVC. Main changes with previous works involve the recently discovery of much younger ages for the main caldera-forming eruption. Much younger ages were also obtained for other important explosive phases. These findings reveal the existence of a much younger long-lived magmatic system with Holocene activity and a high geothermal potential that requires a further assessment for exploration and volcanic hazard purposes.
\end{abstract}

Keywords: Volcano geology, Caldera's geologic mapping, Geothermal field, Los Humeros complex

\section{Resumen}

Esta es una versión actualizada del mapa geológico del Complejo Volcánico Los Humeros (CVLH) y campo geotérmico, basada en una caracterización actualizada de las unidades litológicas y contactos, características estructurales, estratigrafía y fechamientos radiométricos recientes con base en métodos modernos (U/Th, 40Ar/39Ar, Carrasco-Núñez et al., 2017, en prensa), junto con el uso del modelo digital de terreno de alta resolución a 1m e imágenes ópticas de Google Earth. Las mejoras de esta versión incluyen una propuesta de una secuencia estratigráfica refinada, una clasificación revisada de cada unidad litoestratigráfica, la actualización de rasgos estructurales y datos geocronológicos; todo lo cual en conjunto permite constreñir una nueva historia evolutiva volcánica para el CVLH. Los cambios principales con respecto a los trabajos previos implican el reciente descubrimiento de edades mucho más jóvenes para la erupción principal que formó la caldera. Se obtuvieron también edades mucho más jóvenes para otras fases explosivas importantes. Estos hallazgos revelan la existencia de un sistema magmático mas jóven y de larga duración con actividad Holocénica que implican un alto potencial geotérmico que requiere una reevaluación para fines de exploración y de peligros volcánicos.

Palabras clave: Geología volcánica, Cartografía geológica de una caldera, Campo geotérmico, Complejo de Los Humeros

\footnotetext{
¿ C G. Carrasco-Núñez, J. Hernández, L. De León, P. Dávila, G. Norini, J. P. Bernal, B. Jicha, M. Navarro, P. López-Quiroz. Published by Terra Digitalis. This is an Open Access article distributed under the terms of the Creative Commons Attribution License (https://creativecommons.org/licenses/by-nc-sa/4.0/),
}

which permits non-commencial sharing of the work and adaptions, provided the original work is properly cited and the new creations are licensed under identical terms.

*E-mail address: gerardoc@geociencias.unam.mx 


\section{Introduction}

The Los Humeros Volcanic Complex (LHVC), located in the northernmost part of the eastern sector of the Trans-Mexican Volcanic Belt (TMVB), is the third most important geothermal field in Mexico, with a current installed capacity of 65 MW of electric power generated by around 20 wells out of a total of about 50 drilled wells (Fig. 1). The LHVC is a multiple large caldera structure with a complex evolution involving at least two major caldera-forming eruptions, generating the Los Humeros caldera and the nested Los Potreros caldera, with alternated episodes of effusive and explosive eruptions since the Pleistocene to the Holocene (Ferriz and Mahood, 1984; Carrasco-Núñez et al., 2017, in press).

Several pioneer geologic maps were constructed during the early stages of the geothermal exploration program in the late 70's-early 80's by the staff of Federal Commission of Electricity (C.F.E.) (e.g. Pérez-Reynoso, 1978; De la Cruz, 1983; Yáñez and García, 1982; Ferriz and Mahood, 1984). Among these works, the map of Ferriz and Mahood (1984) provided the most comprehensive summary of the geology, stratigraphy and evolution of the Los Humeros caldera complex, supported by a number of K/Ar radiometric dates. With all these available data, a more recent geologic map was compiled and a reduced version was published as part of an article that includes a comprehensive analysis of the subsurface stratigraphy of the geothermal field (Carrasco-Núñez et al., 2017).

Nevertheless, the renovated interest to study the LHVC, as a basis to reassess its geothermal potential, create the necessity to develop an updated geologic map. Recent high-precision U/Th and ${ }^{40} \mathrm{Ar} /{ }^{39} \mathrm{Ar}$ radiometric dating, presented in a companion paper (Carrasco-Núñez et al., 2017, in press), provide strong support to the new stratigraphic scheme, together with the use of $1 \mathrm{~m}$ resolution digital terrain model and a thorough revision of the structural features, stratigraphic relationships and a revised geochemical classification of each lithostratigraphic unit. The new version of the LHVC geologic map (See Plate 1) shows a detailed account and complete stratigraphic framework providing information of each of the different lithostratigraphic units exposed in an adequate scale, serving as a main basic reference for further studies. The new ${ }^{14} \mathrm{C}$ dating, coupled with recent geochronology, as well as the field geological features and stratigraphic definitions provided in this study, represent a highly relevant data set, for further asses the most complete and new evolutionary volcanic history for LHVC.

\section{Methodology}

After an extensive review of all the existing cartography for the LHVC, we identify some inconsistencies in the stratigraphic units, lithological contacts and structures, accompanied by rather low-precision dating framework. Therefore, a revised geological map to resolve the inconsistencies was largely overdue.
This work represents the result of more than 10 years of fieldwork at the LHVC performed during many field campaigns. During the last two years, the authors worked exhaustively on specific objectives, in particular defining contacts previously not well constrained, verifying faults, sampling rocks and paleosols, acquiring structural data, describing eruptive units and lithologies, and establishing petrological, geochemical and geochronological constrains on its evolution.

The combined use of a new high-resolution Digital Terrain Model with $1 \mathrm{~m}$ resolution obtained by digital photogrammetry of $0.5 \mathrm{~m}$ multispectral satellite optical images allowed us to map in detail structural and morphological features (particularly in the geothermal field), refine rock unit contacts (especially in the forested areas) and revise in greater detail the location of volcanic vents. Systematic sampling and field verification on key outcrops allowed to collect data and samples for petrographic and geochemical characterization of the rock units that integrate the revised stratigraphic column. We include a new classification of the LHVC based on the Total Alkali Silica diagram (Fig. 2 ), in which we include all the available chemical analysis plus 111 new ones obtained for this work. Geochemical data are provided in Table 1 (see Supplementary material).

Modern, high-precision radiometric dating, including those obtained by U/Th (Bernal et al, 2014), and ${ }^{40} \mathrm{Ar} /{ }^{39} \mathrm{Ar}$ (reported in Carrasco-Núñez et al., 2017, in press) along with new ${ }^{14} \mathrm{C}$ dating are presented here (calibrated by Calib 7.1 program to INTCAL 13; Stuiver et al., 2017), and represents a significant improvement with respect to previous K/Ar geochronology, for the caldera units (Ferriz and Mahood, 1984) and the pre-caldera formations (Yáñez and García, 1982). All the new and revised data were integrated in a GIS-based geologic map.

\section{Geologic and tectonic setting}

The LHVC is the easternmost Quaternary caldera of the TMVB, a Miocene-Quaternary continental volcanic arc resulting from the subduction of the Cocos and Rivera plates beneath the North American plate along the Middle American trench (Ferrari et al., 2012, and references therein). The volcanic complex is located to the northwest of the Pico de Orizaba - Cofre de Perote volcanic range. In this area, the volcanic rocks of the TMVB stand on top of an intrusive, metamorphic and sedimentary sequence (described in Section 1.1). The volcanic activity in the area, prior to the emplacement of the LHVC, is represented by a thick sequence of 10.5-1.55 Ma andesites and basaltic andesitic lava flows whose upper part is known as Teziutlán formation (Yañez and García, 1982; Cedillo-Rodríguez, 1984, 1997, 1999; Ferriz and Mahood, 1984; López-Hernández, 1995; Arellano et al., 2003; Gutiérrez-Negrín and IzquierdoMontalvo, 2010).

The LHVC basement has been deformed by two main tectonic events: The Late Cretaceous to Paleocene contractile Laramide Orogeny, which produced NW-SE thrusts and folds affecting the Mesozoic sedimentary and older rocks (e.g. CamposEnriquez and Garduño-Monroy, 1987; López-Hernández, 1995; 


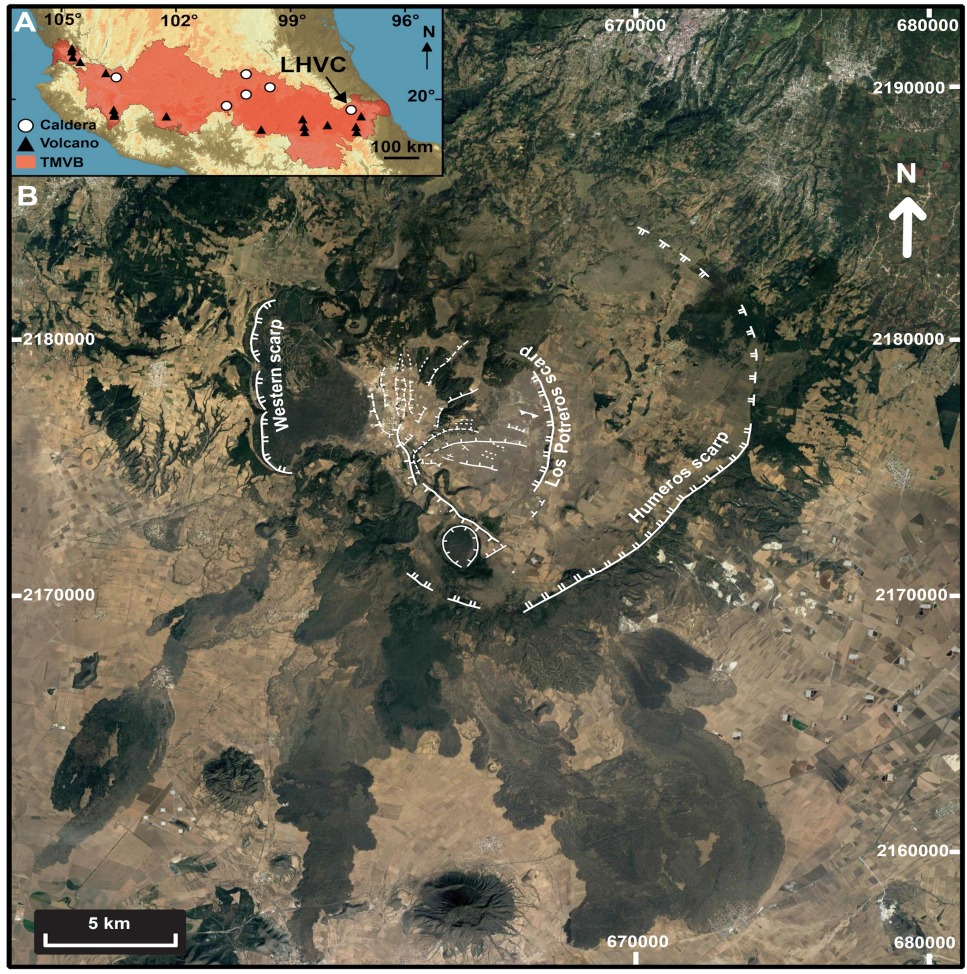

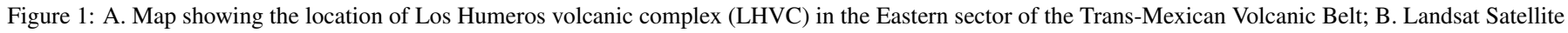
image (Google Earth) showing the main structures of the inner caldera where the geothermal field is located. The main scarps of Los Potreros and Los Humeros caldera are shown, related to the two principal caldera-forming events of the LHVC.

Figura 1: A. Mapa que muestra la localización del Complejo Volcánico de Los Humeros (CVLH) en el sector oriental del Cinturón Volcánico Trans-Mexicano;

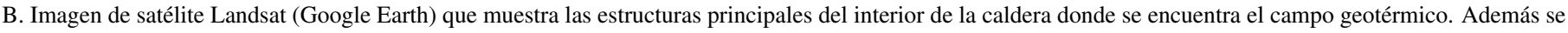

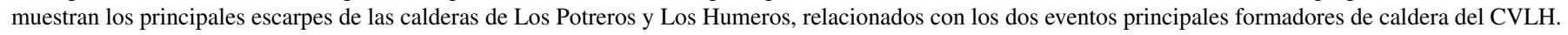

Fitz-Díaz et al., 2017), followed by one, or more, not welldefined Eocene-Pliocene extensional and transtensional phases that produced N-S to NE-striking faults (e.g. Campos-Enriquez and Garduño-Monroy, 1987; López-Hernández, 1995).

The emplacement of the LHVC is associated with prominent Pleistocene-Holocene volcanotectonic structures (e.g. Ferriz and Mahood, 1984; Norini et al., 2015). Quaternary semicircular scarps define the edge of the Los Humeros and Los Potreros calderas (Fig. 1). These morphological rims have been interpreted as landslide scarps generated by the Los Humeros and Los Potreros calderas collapse along outward dipping ring faults (Norini et al., 2015). The outward dipping geometry of the ring faults has been recently imaged by a magnetotelluric (MT) survey of the LHVC (Arzate et al., 2017). The geometry of the Los Humeros caldera recalls an asymmetric trapdoor structure, with the major vertical displacements occurring along the SW sector of the caldera ring faults (Norini et al., 2015). The Los Potreros caldera floor is also traversed by a prominent fault system, made by dip-slip NNW-SSE, N-S, NESW and E-W curvilinear fault splays related to the probable active resurgence of the Los Potreros caldera floor (Fig. 1) (Norini et al., 2015). The subvertical inward dipping geometry of these faults has been also recently observed by MT data (Arzate et al., 2017). The producing geothermal wells are lo- cated along the main NNW-SSE active faults (Maxtaloya-Los Humeros faults) or near pervasive $\mathrm{N}-\mathrm{S}$ striking fault splays in the central-northern sector of the Los Potreros caldera (Norini et al., 2015).

\section{Stratigraphic units}

A description of each lithostratigraphic unit is provided as follows. A summary of the main features of each unit can be found in Table 2. A compilation of the radiometric dating used in this map is shown in Table 3. See both tables in Supplementary material.

\subsection{Pre-caldera basement and intrusive rocks}

\subsubsection{Pz/K.- Granodiorites and schists}

The regional basement is formed by a Paleozoic-Cretaceous crystalline complex known as the Teziutlán Massif, which includes green schists with quartz-muscovite, hipidiomorphic granodiorites composed of plagioclase, $\mathrm{K}$ feldspar, quartz, biotite and hornblende, as well as granites with K/Ar ages of 131 and 246 Ma (Yáñez and García, 1982). The Teziutlán Massif outcrops are located to the north and northeastern sides of the 
Los Humeros caldera, to the western side of Altotonga city at the Chignautla range. This basement is partially covered by a Mesozoic sedimentary sequence, which corresponds to the Sierra Madre Oriental fold and thrust province, described below.

\subsubsection{K/J.- Limestones and shales}

The regional basement is overlain by a Jurassic sedimentary sequence, which corresponds mainly to highly folded and thrusted shales and limestones (Viniegra-Osorio, 1965). Outcrops around the caldera mainly consists of thick sandstone strata with red shale lenses that correspond to the Cahuasas Formation (Carrillo-Bravo, 1961), clayey and calcareous rocks from the Tamán Formation, and limestone and dolomites of the
Pimienta Formation (López-Ramos, 1979).

The Cretaceous is represented by carbonate facies exposed around most of the extra-caldera region. These rocks correspond to the Tamaulipas Inferior and Tamaulipas Superior Formations, composed of clayey limestones with flint intercalations (López-Ramos, 1979) that laterally shift to reef limestone facies of the Orizaba Formation (Viniegra-Osorio, 1965). Several clayey limestone formations, including the Maltrata, Agua Nueva, San Felipe, and Méndez Formations overlie the Orizaba Formation in a transitional manner.

\subsubsection{Tig.-Granites}

The Mesozoic sedimentary sequence is intruded by a phaneritic granite and granodiorite stock composed of quartz, K feld-

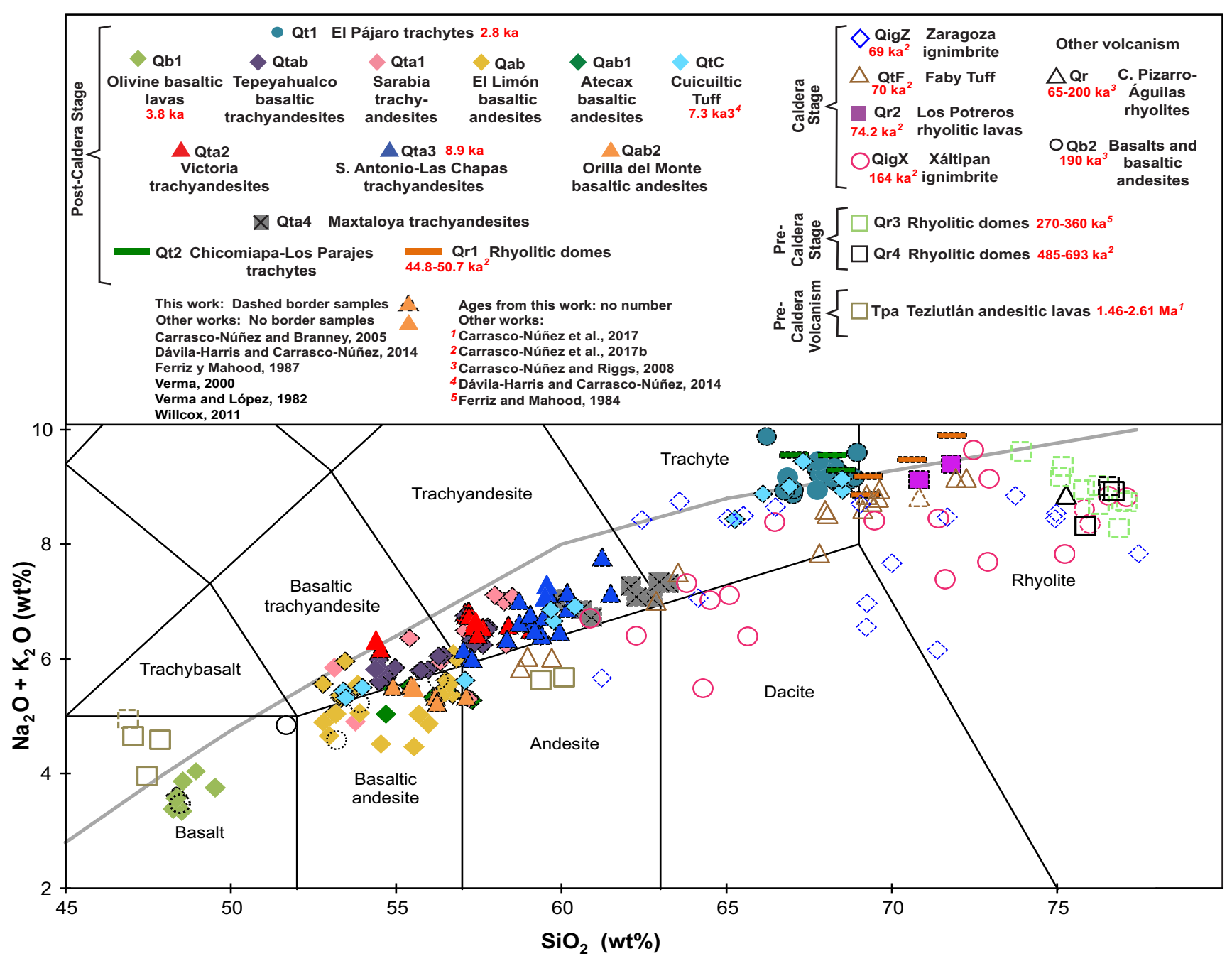

Figure 2: Total Alkali $(\mathrm{Na} 2 \mathrm{O}+\mathrm{K} 2 \mathrm{O})$-Silica ( $\mathrm{SiO} 2)$ diagram (Le Maitre et al., 1989) for all the lithostratigraphic rock units comprising the LHVC grouped as Pre-caldera, caldera and post-caldera groups. Source data for geochemistry and geochronology is shown in the big box for this work and other papers. All samples are normalized to $100 \%$ in anhydrous basis.

Figure 2: Diagrama de Álcalis Totales (Na2O + K2O) vs SiO2 (Le Maitre et al., 1989) para todas las unidades litoestratigráficas que comprenden el CVLH, agrupadas como: Pre-caldera, caldera y post caldera. La fuente de los datos geoquímicos y de geocronología se muestra en el recuadro grande. Todas las muestras están normalizadas al $100 \%$ en base anhidra. 
spar, plagioclase, and biotite with a K/Ar age of 14.5 to $31 \mathrm{Ma}$ (Yáñez and García, 1982). New U/Pb zircon data is reported in this paper, giving an age of $15.12 \pm 0.64 \mathrm{Ma}$ (Table 3, see Supplementary material).

\subsection{Pre-caldera volcanism}

\subsubsection{Tm.- Miocene dacitic and andesitic lava flows}

Miocene andesitic volcanism is associated with the Cerro Grande volcanic complex with K/Ar ages of 8.9 to $11 \mathrm{Ma}$ (Carrasco-Núñez et al. 1997; Gómez-Tuena and Carrasco-Núñez, 2000). This can be correlated with the Cuyoaco Andesite Formation (López-Hernández, 1995) or the Alseseca Andesite (Yáñez and García, 1982) dated at K/Ar at $10.5 \pm 0.7 \mathrm{Ma}$; the latter are dark-gray porphyritic andesite-dacite lava flows with plagioclase, pyroxene, biotite and hornblende. Outcrops of this sequence are located at the western side of the caldera.

\subsubsection{Tpa.- Pliocene Teziutlán andesitic lava flows}

The unit consists of massive, grey, porphyritic andesitic lava flows, composed of plagioclase, two-pyroxene phenochrysts and minor dark grey olivine-bearing basalts. Even though pre-caldera outcrops are scarce, there are a few exposures to the north side of the caldera, to the east of the town of Zaragoza and in the surroundings of the City of Teziutlán. Several ${ }^{40} \mathrm{Ar} /{ }^{39} \mathrm{Ar}$ ages of this unit have been reported, varying from $1.46 \pm 0.31$ to $2.61 \pm 0.43 \mathrm{Ma}$ (Carrasco-Núñez et al., 2017), with an older K-Ar age of 3.5 Ma reported by Yáñez and García (1982).

\subsection{Other volcanism}

\subsubsection{Qacp2-Qacp3.- Cofre de Perote andesitic and trachyan- desitic lava flows}

These units are associated to the nearby Cofre de Perote shield-like compound volcano, formed by a succession of andesitic-trachyandesitic to dacitic domes and associated breccias composed of plagioclase and two pyroxenes. This unit has ages between $510 \pm 60$ and $307 \pm 35 \mathrm{ka}\left({ }^{40} \mathrm{Ar} /{ }^{39} \mathrm{Ar}\right.$, Carrasco-Núñez et al., 2010). Outcrops are located at the southeastern side of the caldera.

\subsubsection{Qr.- Cerro Pizarro-Águilas rhyolitic domes}

Cerro Pizarro consists of a complex polygenetic isolated dome system (Riggs and Carrasco-Núñez, 2004; Carrasco-Núñez and Riggs, 2008), which involves the emplacement of a vitrophyric dome $\left({ }^{40} \mathrm{Ar} /{ }^{39} \mathrm{Ar}: 220 \pm 60 \mathrm{ka}\right)$, followed by the intrusion of a cryptodome $\left({ }^{40} \mathrm{Ar} /{ }^{39} \mathrm{Ar}\right.$ : $\left.115 \pm 12 \mathrm{ka}\right)$, and explosive deposits $\left({ }^{40} \mathrm{Ar} /{ }^{39} \mathrm{Ar}\right.$ : $\left.65 \pm 10 \mathrm{ka}\right)$. Cerro Pizarro is located SW of Los Humeros caldera, but is not part of this volcanic system.

The Águilas dome, located to the NW of Cerro Pizarro, consists of light-gray flow banded porhyritic rhyolitic lava flow, comprising quartz, $\mathrm{K}$ feldespar, plagioclase and biotite. The eroded morphology shown by the volcanic dome, suggests an age older than the Cerro Pizarro dome.

\subsubsection{Qb2.- Basaltic and basaltic andesite lava flows}

The unit is composed of highly to moderate vesicular, porphyritic basalts and scoriaceous basaltic-andesite lava flows. Both lava flows are black and are composed of plagioclase, pyroxene and olivine, within a glassy and microlithic matrix. Basaltic andesite outcrops are located in a sequence of Cerro Tezontepec scoria cone and to the south side of Las Águilas dome, surrounding Cerro Pizarro dome. The basaltic lava flows are isolated outcrops to the south and to the northern side of the caldera, forming the Cerro Bola scoria cone. Nevertheless, it is possible that this basaltic sequence is not directly associated to the caldera's volcanic activity. This unit has an ${ }^{40} \mathrm{Ar} /{ }^{39} \mathrm{Ar}$ age of $190 \pm 20$ ka (Carrasco-Núñez and Riggs, 2008).

\section{Los Humeros evolutionary stages}

\subsection{Pre-caldera stage}

\subsubsection{Qr3.- Rhyolitic domes}

This unit consists of light-gray flow banded, porphyritic, rhyolitic domes with a mineral assemblage of quartz, plagioclase and biotite. A special characteristic is the presence of pristine spherulites and lythophysae with diameters up to 0.3 $\mathrm{m}$. Outcrops are located near the western caldera rim, and to the northwestern and north sides out of the caldera. This unit has U/Th zircon ages of $270 \pm 17 \mathrm{ka}$ and $155.7 \pm 4.9 \mathrm{ka}$, (CarrascoNúñez et al., 2017, in press) and was previously dated by K/Ar method at $220 \pm 20 \mathrm{ka}$ (Ferriz and Mahood, 1984). The younger age $(155.7 \mathrm{ka})$ is close to the age of the Xaltipan ignimbrite, but represent outer volcanism that is linked with the western dome field, that is why is included in this unit.

\subsubsection{Qr4.- Rhyolitic lavas and dome}

This unit is composed of light-gray, flow banded, and porphyritic rhyolitic lavas with a mineral assemblage of quartz, plagioclase and biotite. It is exposed in the caldera's southern rim, at $16 \mathrm{~km}$ to the W-NW from Perote and at a dome cut by the western scarp. Carrasco-Núnez et al. (2017, in press) obtained two ${ }^{40} \mathrm{Ar} /{ }^{39} \mathrm{Ar}$ dates of $485.7 \pm 2.2$ and $693 \pm 1.7 \mathrm{ka}$ for this unit, which is close to the age of $470 \pm 40$ ka reported by Ferriz and Mahood (1984).

\subsection{Caldera stage}

\subsubsection{QigX.- Xáltipan ignimbrite}

According to Ferriz and Mahood (1984), the eruption of the Xáltipan ignimbrite led to the collapse of Los Humeros caldera. The Xáltipan ignimbrite is composed of aphyric high-silica rhyolitic pumice and porphyritic biotite-bearing rhyodacitic pumice in minor proportions. Most of the pumice clasts contain plagioclase, pyroxene, biotite and scarce hornblende. The ignimbrite represents a minimum of $115 \mathrm{~km}^{3}$ DRE of erupted magma and covered $3500 \mathrm{~km}^{2}$. To the northeast side it extends for $50 \mathrm{~km}$ 
away from the caldera, and flowed through the canyons probably reaching the coastal plain. To the southeast side, the flow of the ignimbrite was hindered by the topography and barely reached the city of Xalapa. In the south and southwestern sides of the caldera, the ignimbrite covered a flat terrain, and to the west it crossed the Tlaxco range (Ferriz and Mahood, 1984). In this work, we identified new outcrops located to the NNW side of the caldera, surrounding the Ocotlán and Zaragoza towns; other outcrops are located to the northeastern side of Atecax and surrounding Tenextepec villages. This unit yielded U/Th ages of $158.4 \pm 8.3$ and $180 \pm 13 \mathrm{ka}$ and a ${ }^{40} \mathrm{Ar} /{ }^{39} \mathrm{Ar}$ age of $153 \pm$ $13 \mathrm{ka}$, which provide an error-weighted mean $\mathrm{U} / \mathrm{Th}-{ }^{40} \mathrm{Ar} /{ }^{39} \mathrm{Ar}$ age of $164.0 \pm 4.2 \mathrm{ka}$ (Carrasco-Núñez et al. in press). This age is significantly younger than the K/Ar date of $460 \pm 20$ ka reported by Ferriz and Mahood (1984), but is in excellent agreement with previous ${ }^{40} \mathrm{Ar} /{ }^{39} \mathrm{Ar}$ dating by Wilcox (2011) and Aliaga-Campuzano et al. (2017).

\subsubsection{QtF.- Faby tuff}

This unit was defined by Ferriz and Mahood (1984) as a succession of 15 andesitic to rhyolitic, plinian pumice fall layers. However, it is important to point out that several paleosols occur between these fall layers, indicating a sequence produced not in a single eruption, but as a result of multiple eruptive episodes. Most of the pumice clasts contain two pyroxene and scarce hornblende. This sequence represents the second major explosive eruption of Los Humeros caldera, but associated to high eruptive columns that gave rise to widely distributed pumice sequences, with a preferred emplacement direction to the east, southeast and south of the caldera, attributed to predominant SE oriented wind during the eruption (Willcox, 2011). The type locality is a quarry to the southeast of Los Humeros caldera and $2.5 \mathrm{~km}$ north of El Frijol Colorado town. New reported ${ }^{40} \mathrm{Ar} /{ }^{39} \mathrm{Ar}$ ages (Carrasco-Núñez et al., 2017, in press) of 70 $\pm 23 \mathrm{ka}$ indicates a much younger age than previously reported such as $270 \pm 30$ and $19 \pm 40 \mathrm{ka}$ (K/Ar, Ferriz y Mahood, 1984) and $260 \pm 40 \mathrm{ka}$ and $140 \pm 20 \mathrm{ka}\left({ }^{40} \mathrm{Ar} /{ }^{39} \mathrm{Ar}\right.$, Willcox, 2011). The Faby tuff has an erupted volume of $10 \mathrm{~km}^{3}$ of Dense Rock Equivalent (Ferriz y Mahood, 1984).

\subsubsection{Qr2.- Los Potreros rhyolitic lavas}

This unit consists of gray, vertical flow banded, glassy-porphyritic rhyolitic lavas with scarce spherulites. Its mineral assemblage consists of plagioclase, alkali feldespars and scarce pyroxene, quartz microlites and microcrystals. Outcrops consist of irregular lavas, which are underlying the Zaragoza member. This unit has a U/Th zircon age of $74.2 \pm 4.5 \mathrm{ka}\left({ }^{40} \mathrm{Ar} /{ }^{39} \mathrm{Ar}\right.$, Carrasco-Núñez et al., 2017, in press) and was previously dated at $100 \mathrm{ka} \pm 30(\mathrm{~K} / \mathrm{Ar})$ by Ferriz and Mahood (1984).

\subsubsection{QigZ.- Zaragoza ignimbrite}

This ignimbrite is the product of the second major calderaforming eruption of Los Humeros that formed the $10 \mathrm{~km}$ in diameter Los Potreros caldera at $0.1 \mathrm{Ma}$, erupting nearly $15 \mathrm{~km}^{3}$ of DRE (Carrasco-Núñez and Branney, 2005). The unit has a thickness varying from $<2$ to $16 \mathrm{~m}$, and is composed of juvenile fragments of white to gray rhyodacite, black andesite, subordinated mingled pumice, scarce brown (mixed) pumice, dacitic pumice and trace of basaltic andesitic pumice (Ferriz and Mahood, 1987). Most of the pumice clasts have a similar mineralogy, and contain microphenocrysts of plagioclase, pyroxene and oxides in a glassy groundmass. The Zaragoza ignimbrite shows an unusual double compositional zonation (CarrascoNúñez and Branney, 2005) resulted from complex mixed and mingled magmatic processes (Carrasco-Núñez et al., 2012).

The basal part of the unit is composed predominantly of rhyodacitic pumice, grading upwards to dacitic composition, and rhyodacitic pumice atop. This ignimbrite deposit has a radial distribution surrounding the caldera, reaching distances greater than $18 \mathrm{~km}$ from the caldera rim. Several outcrops are located at the Los Potreros fault scarp to the northwestern side of the caldera, to the east side of Ocotlán town and to the southeastern side of Zaragoza town. Other outcrops are located surrounding Cerro Pizarro dome. Carrasco-Núñez et al. (2017, in press) provided a new ${ }^{40} \mathrm{Ar} /{ }^{39} \mathrm{Ar}$ age of $69 \pm 16 \mathrm{ka}$, which is much younger than those reported previously of $140 \pm 12 \mathrm{ka}\left({ }^{40} \mathrm{Ar} /{ }^{39} \mathrm{Ar}\right.$, Willcox, $2011)$ or estimated at $100 \pm 30 \mathrm{ka}(\mathrm{K} / \mathrm{Ar}$; Ferriz and Mahood, 1984).

\subsection{Post-Caldera stage}

This includes a Resurgent phase and a Ring-fracture and bimodal phase, which are described as follows:

\subsubsection{Resurgent phase}

\section{Qr1.- Rhyolitic domes}

This unit corresponds to gray color, flow banded, porphyritic rhyolitic domes with a mineral assemblage composed of plagioclase, alkali feldspar and two pyroxenes, embedded in a glassyporphyritic matrix. This sequence was formed in the caldera's interior in a SE direction from Los Humeros town, and other outcrops are located to the northern boundary of the caldera. New U-Th zircon dating indicates an age of $44.8 \pm 1.7 \mathrm{ka}$ and $\left({ }^{40} \mathrm{Ar} /{ }^{39} \mathrm{Ar}\right) 50.7 \pm 6 \mathrm{ka}$ (Carrasco-Núñez et al., 2017, in press), which is younger than the K/Ar previously reported of $60 \pm 10$ ka (Ferriz and Mahood, 1984).

\section{Qt2.- Chicomiapa-Los Parajes trachytic lava flows}

This unit consists of black to dark-gray color, porphyritic trachytic lava flows with plagioclase phenocrysts and two pyroxenes. It is exposed within the caldera's inner sector and also in the northern side. This sequence is overlain by pyroclastic deposits that may correlate with the Cuicuiltic Member.

\section{QXm.- Xoxoctic member}

This member was first described by Ferriz and Mahood (1984) as a dacitic air fall tuff, with olivine pumice. Willcox (2011) described this member as a predominantly Sub-Plinian/Plinian fall with well-sorted, clast supported, angular pumice lapilli and 
lithics. It is overlain by a paleosol and a lava flow that may correlate with the Texcal Member named by Willcox (2011), and locally by volcanic pumice ash that may be derived from Cerro Pizarro (65 \pm 10 ka: ${ }^{40} \mathrm{Ar} /{ }^{39} \mathrm{Ar}$; Carrasco-Núñez and Riggs, 2008). This member is not a mapping unit, because is only present in vertical sections.

\section{Qta4.- Maxtaloya trachyandesitic and trachytic lava flows}

This unit consists of black to dark gray, glassy porphyritic trachyandesitic lavas, with plagioclase, pyroxene, and amphibole phenocrysts. Usually this unit is red-colored due to oxidation and probably to auto-brecciation. Outcrops are present inside Los Humeros caldera, surrounding the Maxtaloya town, but mostly exposed on the inner walls of the Xalapazco crater and Maxtaloya small crater, characterized by oxidation and argilic alteration. This sequence was emitted prior to the eruption of Llano tuff, which has a minimum age of 28,270 $\pm 110 \mathrm{yr}$ B.P. $\left({ }^{14} \mathrm{C}\right.$, Rojas-Ortega, 2016) and overlies the Maxtaloya lava flows.

\section{QLt. - Llano tuff}

This unit was described by Ferriz and Mahood (1984) as the Llano ignimbrite, and consists of a partly welded andesitic ignimbrite composed of blocks, bombs, lapilli and ash. According to Rojas-Ortega (2016), the Llano tuff consists of a brown to red, non-welded pyroclastic deposit, which is composed of coarse lapilli and blocks, predominantly with pumice, lithic clasts, glassy fragments and reddish lavas. The formation of this deposit is associated to the Xalapazco volcano explosive eruption and possible collapse (Rojas-Ortega, 2016). Pumice clasts are gray-colored, and have porphyritic and trachytic texture, with plagioclase, sanidine, hypersthene and augite as phenocrysts, and assimilated clasts. In the proximal zones of the Xalapazco crater, the Llano Tuff is overlain by the Cuicuiltic Member and overlies the Maxtaloya lava flows. A paleosol sample was collected at the top of the Llano Member yielding a ${ }^{14} \mathrm{C}$ age of $28,270 \pm 110 \mathrm{yr}$ B.P. (Cal BP 31642 to 32647 yr, Rojas-Ortega, 2016). This member is not a mapping unit, because is only present in vertical sections.

\subsubsection{Ring-fracture and bimodal phase}

\section{Qta3.- San Antonio-Las Chapas trachyandesitic lava flows}

This unit corresponds to a dark-gray color, moderate to highly vesicular, brecciated trachyandesite lavas, with glassy-porphyritic and trachytic texture. Mineral assemblage consists of plagioclase, two pyroxene and scarce olivine. It is exposed within the caldera margins and also in the northern side of the caldera; apparently most of this sequence was erupted through the San Antonio volcano. Other outcrops are located $7 \mathrm{~km}$ to the SW of Teziutlán, discordantly underlain by the Cuicuiltic Member. It is considered that these lava flows erupted through a vent located $1 \mathrm{~km}$ to the NW of Las Chapas town. This unit was dated by ${ }^{14} \mathrm{C}$ in charcoal at the lower paleosol, and has an age of 8910 \pm 30 yr B.P. (Cal BP 10185 to 9910 yr, Table 4 (see Supplementary material)).
Qab2.- Orilla del Monte basaltic andesite lava flows

This unit is composed of black to dark-gray color, moderately vesiculated basaltic andesite lava flows and andesitic flows in minor proportions, with varying glassy-porphyritic texture. The mineral assemblage consists of plagioclase, pyroxene and minor olivine phenocrysts. It is exposed inside the caldera, and also at the $\mathrm{E}$ and NE side. To the eastern side of the caldera, near the village Orilla del Monte, there is an outcrop, which is overlain by the Cuicuiltic Tuff, thus it is inferred that these lavas were erupted at approximately the same time of San AntonioLas Chapas lava flows, at near $8.9 \mathrm{ka}$.

\section{Qtc.- Cuicuiltic Member}

The Cuicuiltic member represents the last major explosive event registered at Los Humeros caldera, during the Holocene, combining simultaneously both, Plinian and Strombolian activities (Dávila-Harris and Carrasco-Núñez, 2014). This member consists of alternated fallout deposits of white trachydacitic pumice and black basaltic andesite scoria, and it has been subdivided in 9 units. The mineral assemblage within pumice clasts consists of plagioclase, two pyroxenes, biotite, $\mathrm{K}$ feldspar and hornblende. Trachydacitic layers are dispersed from the center towards NW, and the andesitic units have maximum thicknesses over SE and NE sides of the caldera, suggesting active vents connected underneath by one or several hidden fractures at depth. This sequence yields a maximum ${ }^{14} \mathrm{C}$ age of 7,355 \pm 105 yr B.P. (Cal BP 7982 to 8371 yr, Dávila-Harris and Carrasco-Núñez, 2014).

\section{Qta2.- Victoria trachyandesitic lava flows}

This unit corresponds to black, vesiculated blocky lavas of trachyandesitic composition and basaltic trachyandesitic lavas in minor proportions, with glassy matrix, porphyritic-trachytic texture; plagioclase, two pyroxene and olivine are present as phenocrysts. These lava flows were generated through the south ring-fracture, and are distributed to the southwestern side of the caldera, near Guadalupe Victoria and Madero towns.

\section{Qtab.- Tepeyahualco basaltic trachyandesitic lava flows}

This unit consists of black color, aphanitic to porphyritic texture, trachyandesitic and basaltic trachyandesitic lava flows with plagioclase, two pyroxene phenocrysts. These flows erupted through south ring-fracture, and are distributed to the south side of the caldera. One of these flows reached a distance of $14 \mathrm{~km}$ from the caldera rim.

\section{Qta1.-Sarabia trachyandesitic lava flows}

The Sarabia trachyandesitic flows correspond to blocky, black color, porphyritic lavas, with low to high vesiculation, usually elongated; the mineral assemblage consists of plagioclase and two-pyroxene phenocrysts. There are basaltic trachyandesitic and andesitic lava flows in minor proportion. Matrix is composed mostly of tabular plagioclase microlites forming a trachytic texture, cryptocrystaline material and glass occurs in minor proportion. These flows erupted through south ringfracture, and are distributed to the south side of the caldera and 


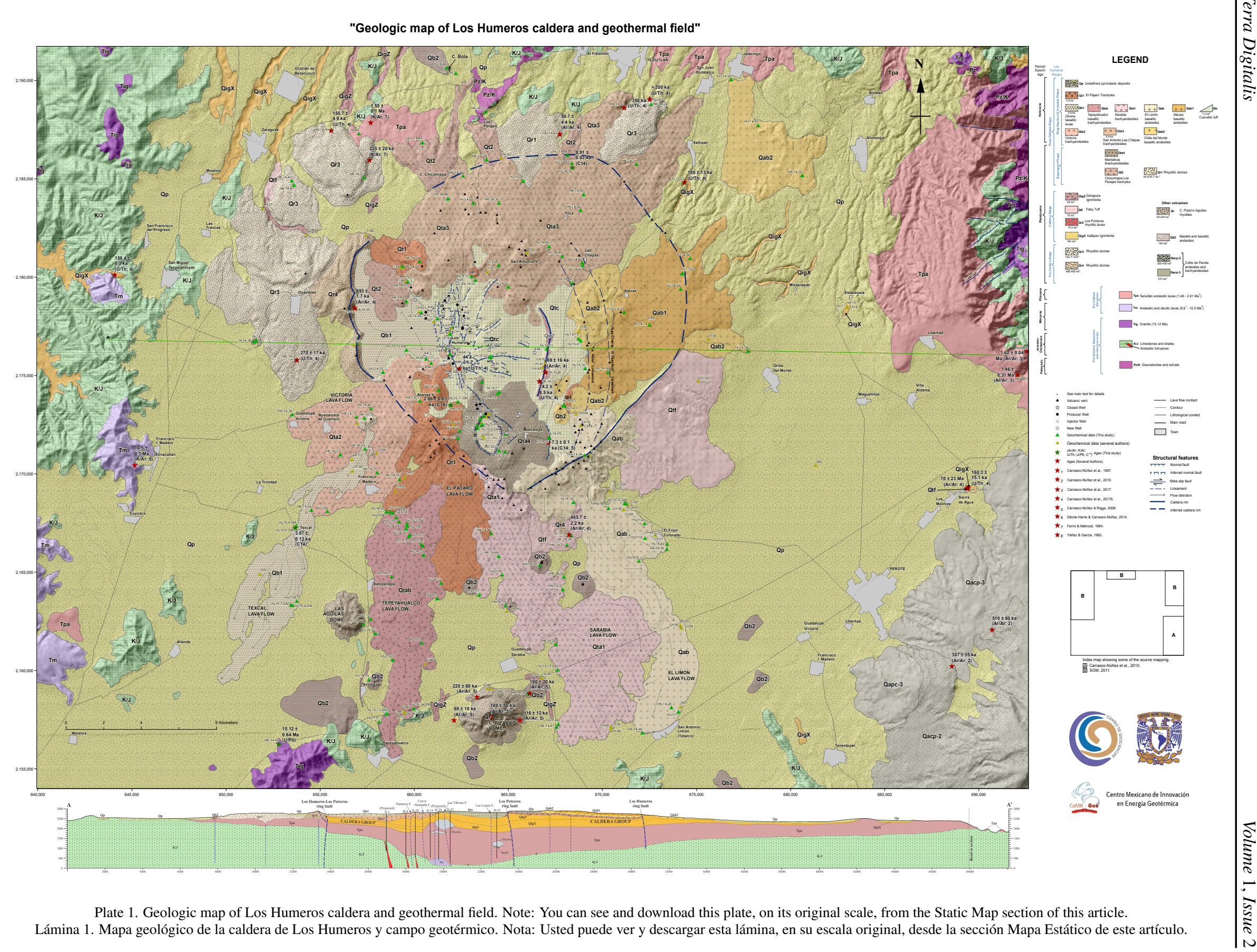


to the eastern side of the Guadalupe Sarabia town. One of these flows reached a length of $13.5 \mathrm{~km}$.

\section{Qab.- El Limón basaltic andesite lava flows}

El Limón lavas consists of basaltic andesite and basaltic trachyandesite flows. This unit is composed of three different blocky lava flows: Flows I and II are black color and vesiculated, the latter flow is characterized by being the most extensive, with a length of $14 \mathrm{~km}$, while flow III is brecciated, to moderately vesiculated. They have a porphyritic and slightly trachytic texture, and are composed of plagioclase, two pyroxene and minor olivine as phenocrysts. These flows also erupted through south ring-fracture, and are distributed in the SSE part of the caldera. They overlie an extra-caldera pumice fall deposit that correlates with the Cuicuiltic Member, thus, it is inferred that has a maximum age of $7.3 \mathrm{ka}$.

\section{Qab1.- Atecax basaltic andesitic lava flows}

This unit consists of brecciated, black, basaltic andesite lava flows. These rocks have variable vesicularities, from low to high with porphyritic texture and glassy matrix with embedded phenocrysts of plagioclase and two pyroxenes. Outcrops are located inside and at the western outer flank of the caldera. It is noteworthy to mention that a few outcrops of these lava flows are overlaying a pyroclastic sequence that may correlate with the Cuicuiltic Member, and therefore its inferred maximum age is $7.3 \mathrm{ka}$ (Dávila-Harris and Carrasco-Núñez, 2014). One of its flows, apparently erupted through a vent located $3 \mathrm{~km}$ to the west of Buenavista village, reached a length of $15 \mathrm{~km}$.

\section{Qb1.- Olivine-bearing basaltic lava flows}

This unit consists of black basaltic lava flows, with partial columnar structure, moderately vesiculated, with a porphyritic texture and a groundmass mainly composed of tabular plagioclase microlites, cryptocrystalline material and glass. Lava flows are composed of plagioclase, olivine and pyroxene as phenocrysts. Apparently, this unit represents one of the last volcanic stages associated to the caldera activity. Outcrops are located at the central part of the caldera inside the Xalapazco crater, and surrounding Los Humeros town, where they overlie the Cuicuiltic Member, and also at the SW of the caldera, nearby Texcal town. A paleosol underlying the latter lava flow outcrop was dated by ${ }^{14} \mathrm{C}$ and has a maximum age of $3,870 \pm 130$ B.P. (Cal BP 3899 to 4628,4638 to 4641,4684 to 4686 , Cal BP 4762 to 4797 , Table 4 (see Supplementary material)).

\section{Qt1.- El Pájaro trachytic lava flows}

This unit consists of black color, flow banded, blocky porphyritic trachytic lava flows, with very low vesicularity, sometimes replaced by silica. These flows are composed of plagioclase, two pyroxenes, and scarce amphibole and quartz phenocrysts, which are embedded in a glassy-cryptocrystalline matrix. Outcrops are located inside the caldera, at the NW of the Los Humeros town, and at the western side of the Xalapazco crater, where this unit overlies the Cuicuiltic Tuff. On the other hand, a charcoal sample collected at the basal part of the flow yielded a ${ }^{14} \mathrm{C}$ age of 2,860 $\pm 30 \mathrm{yr}$ B.P. (Cal BP 3065 to $2920 \mathrm{yr}$, Cal BP 3065 to 2920 yr, Table 4 (see Supplementary material)).

\section{$Q p$ - Undefined pyroclastic deposits}

This unit includes pyroclastic deposits of unknown source, reworked pumice deposits and soil layers. Outcrops are widely distributed around the caldera.

\section{Geochemical characterization}

Geochemical data shows a wide compositional variation for the different volcanic stages, including both subalkaline to alkaline series in TAS diagram (Le Maitre et al., 1989). Older volcanism like Teziutlán lavas (Tpa) are plotted in the alkaline basalt field, and products unrelated to the caldera stages like Cerro Pizarro-Águilas domes (Qr) consist of rhyolites and other lavas $(\mathrm{Qb} 2)$, which varies from basalts to basaltic andesites.

The lithostratigraphic units of the pre-caldera stage (Qr4, Qr3) corresponds to two different episodes of rhyolitic domes. The caldera stage starts with the Xáltipan ignimbrite (QigX), which dominant composition is rhyolitic, but with variations from trachyandesite to trachyte, dacite and less frequently andesitic composition. Faby Tuff (QtF) and Zaragoza ignimbrite (QigZ) exhibit a compositional variation pattern similar to Xáltipan ignimbrite, except that they show a slight increase in alkalis. Los Potreros lavas (Qr2) have a rhyolithic composition. Moreover, the resurgent phase of the post-caldera stage starts with dome emplacement (Qr1) of rhyolitic composition, slightly enriched in alkalis compared with the pre-caldera and caldera groups. They are followed by the emplacement of ChicomiapaLos Parajes lava flows (Qt2) of trachytic composition. Maxtaloya lavas (Qta4) are dominantly trachyandesites, but a few samples correspond to trachytic composition; the latter show a decrease in silica and alkalis, compared with rhyolitic domes and Chicomiapa-Los Parajes lavas. The Ring-fracture and bimodal phase of the post-caldera group are dominated by initial effusive activity of trachyandesitic composition of San AntonioLas Chapas (Qta3) and Victoria lavas (Qta2); the latter with scarce samples that correspond to basaltic trachyandesites.

While Orilla del Monte lavas (Qab2) are of andesitic to basaltic andesitic composition, the Cuicuiltic tuff (QtC) shows a wider composition, from alkaline to subalkaline trachytes, to subalkaline basaltic trachyandesite and trachyandesite. The following activity corresponds to lavas with varying composition from basaltic andesites, basaltic trachyandesites and trachyandesites, from Atexcac to Tepeyahualco lava flows (Qab1, Qab, Qta1, Qtab). Later on, a contrasting effusion of basaltic lavas (Qb1) occurs. The youngest activity corresponds to the emplacement of El Pájaro lava flows (Qt1), which corresponds to alkaline to subalkaline trachyte.

\section{Conclusions}

This updated geologic map, accompanied by a revised stratigraphic framework, provides in-depth information of nineteen 
eruptive units, through time and space. This data set is also supported by the new, more robust radiometric dating, allowing us to propose a new volcanic evolutionary scheme for LHVC, which has important implications on the residence times of the magma bodies and the actual magmatic system (Carrasco-Núñez et al., 2017, in press). LHVC was considered as a middle Pleistocene volcanic center (460 ka; Ferriz and Mahood, 1984). However, the recently published ages (Carrasco-Núñez et al., 2017, in press) reveals a much younger age $(<160-180 \mathrm{ka})$, which together with the new ${ }^{14} \mathrm{C}$ dates (this study) suggest the possibility of extended thermal conditions that have an important impact on both the volcanic hazard assessment and the geothermal potential of the Los Humeros geothermal field (Carrasco-Núñez et al., 2017, in press).

\section{Acknowledgements}

This work was funded by project P05 of the CeMie-GEO Consortium No. 2007032 supported by SENER-CONACYT Sustainability Foundation, and PAPIIT-UNAM grant IN 106314. Partial support was provided by Project GEMEX 268074 (Mexico-European Union). This paper was improved by critical reviews by José Luis Macías and editor Luca Ferrari. We want to thank Geothermoelectric Project Management of the Electricity Federal Commission staff for support during this work, particularly to Magaly Flores, Miguel Ramírez, and Cesar Rosales, as well as to Fidel Cedillo, Germán Ramírez, Mike Branney, Chris Willcox for fruitful discussions and support.

\section{References}

Aliaga-Campuzano, M. d. P., López-Martínez, R., Dávila-Harris, P., EspinasaPereña, R., Castillo, A. E. d., Bernal, J. P., 2017. Timing of speleogenesis of Las Karmidas Cave (Mexico): first description of pseudokarst developed in ignimbrite. International Journal of Speleology 46 (3), doi: 10.5038/1827806X.46.3.2097.

URL: http://scholarcommons.usf .edu/ijs/vol46/iss3/2

Arellano, V. M., García, A., Barragán, R. M., Izquierdo, G., Aragón, A., Nieva, D., 2003. An updated conceptual model of the Los Humeros geothermal reservoir (Mexico). Journal of Volcanology and Geothermal Research 124 (1), 67-88, doi: 10.1016/S0377-0273(03)00045-3.

URL: http://www.sciencedirect.com/science/article/pii/ S0377027303000453

Arzate, J., Corbo-Camargo, F., Carrasco, G., Hernández, J., Yutsis, V., 2017. The los humeros (mexico) geothermal field model deduced from new geophysical and geological data. Geothermics 71 (Supplement C), 200-211, doi: 10.1016/j.geothermics.2017.09.009.

Campos-Enriquez, J., Garduño-Monroy, V. H., 1987. The shallow structure of Los Humeros and Las Derrumbadas geothermal fields, Mexico. Geothermics 16 (5), 539-554, doi: 10.1016/0375-6505(87)90038-1.

URL: http://www.sciencedirect.com/science/article/pii/ 0375650587900381

Carrasco-Núñez, G., Branney, M. J., 2005. Progressive assembly of a massive layer of ignimbrite with a normal-to-reverse compositional zoning: the Zaragoza ignimbrite of central Mexico. Bulletin of Volcanology 68 (1), 3, doi: 10.1007/s00445-005-0416-8.

URL: https://link.springer.com/article/10.1007/ s00445-005-0416-8

Carrasco-Núñez, G., López-Martínez, M., Hernández, J., Vargas, V., 2017. Subsurface stratigraphy and its correlation with the surficial geology at Los
Humeros geothermal field, eastern Trans-Mexican Volcanic Belt. Geothermics 67 (Supplement C), 1-17, doi: 10.1016/j.geothermics.2017.01.001.

URL: http://www.sciencedirect.com/science/article/pii/ S0375650517300020

Carrasco-Núñez, G., McCurry, M., Branney, M. J., Norry, M., Willcox, C., 2012. Complex magma mixing, mingling, and withdrawal associated with an intra-Plinian ignimbrite eruption at a large silicic caldera volcano: Los Humeros of central Mexico. GSA Bulletin 124 (11-12), 1793-1809, doi: 10.1130/B30501.1.

URL: https://pubs.geoscienceworld.org/ gsabulletin/article/124/11-12/1793/125773/

complex-magma-mixing-mingling-and-withdrawal

Carrasco-Núñez, G., Riggs, N. R., 2008. Polygenetic nature of a rhyolitic dome and implications for hazard assessment: Cerro Pizarro volcano, Mexico. Journal of Volcanology and Geothermal Research 171 (3), 307-315, doi: 10.1016/j.jvolgeores.2007.12.002.

URL: http://www.sciencedirect.com/science/article/pii/ S0377027307004027

Carrasco-Núñez, G., Siebert, L., Díaz-Castellón, R., Vázquez-Selem, L., Capra, L., 2010. Evolution and hazards of a long-quiescent compound shield-like volcano: Cofre de Perote, Eastern Trans-Mexican Volcanic Belt. Journal of Volcanology and Geothermal Research 197 (1-4), 209-224, doi: 10.1016/j.jvolgeores.2009.08.010.

URL: http://www.sciencedirect.com/science/article/pii/ S0377027309003229

Carrasco-Núñez. G., Bernal, J.P., Jicha, B., Dávila, P., Giordano, G., Hernández, J., 2017. Reappraisal of Los Humeros caldera, revealed by new U/Th and 40ar/39ar dating. Geochemistry, Geophysics, GeosystemsIn press.

Carrasco-Núñez, G., Dávila-Harris, P., Riggs, N.R., Ort, M.H., Zimmer, B.W., Willcox, C.P., Branney, M.J., 2012. Recent explosive volcanism at the eastern Trans-Mexican Volcanic Belt. The Geological Society of America 25, $83-113$.

Carrasco-Núñez, G., Gómez-Tuena, A., Lozano, L., 1997. Geologic map of Cerro Grande volcano and surrounding area, Central México. Geological Society of America Maps and Charts series MCH 81.

Carrillo-Bravo, J., 1961. Geologia del Anticlinorio Hizachal-Peregrina al NW de Ciudad Victoria Tamps. IN SPANISH. Geology of the HuizachalPeregrina Anticline in The N-W of Victoria Tamps City. Boletín de la Asociación Mexicana de Geólogos Petroleros., 1-98.

URL: http://archives.datapages.com/data/amgp/pdf - content/ 1961/1961_Ene_Feb_01X.htm

Cedillo-Rodríguez, F., 1997. Geología del subsuelo del campo geotérmico de Los Humeros, Pue. Comisión Federal de Electricidad-Gerencia de Proyectos Termoeléctricos, Residencia Los HumerosInternal Report HU/RE/03/97.

Cedillo-Rodríguez, F., 1999. Modelo hidrogeológico de los yacimientos geotérmicos de Los Humeros, Puebla, México. Geotermia, Revista Mexicana de Geoenergía 15, 159-170.

De la Cruz, V., 1983. Estudio geológico a detalle de la zona geotérmica Los Humeros, Puebla. Comisión Federal de Electricidad. Gerencia de Proyectos Geotermoeléctricos. Departamento de Exploración, 51Exploration report $10 / 83$.

Dávila-Harris, P., Carrasco-Núñez, G., 2014. An unusual syn-eruptive bimodal eruption: The Holocene Cuicuiltic Member at Los Humeros caldera, Mexico. Journal of Volcanology and Geothermal Research 271 (Supplement C), 24-42, doi: 10.1016/j.jvolgeores.2013.11.020.

URL: http://www.sciencedirect.com/science/article/pii/ S0377027313003569

Ferrari, L., Orozco-Esquivel, T., Manea, V., Manea, M., 2012. The dynamic history of the Trans-Mexican Volcanic Belt and the Mexico subduction zone. Tectonophysics 522 (Supplement C), 122-149, doi: 10.1016/j.tecto.2011.09.018.

URL: http://www.sciencedirect.com/science/article/pii/ S0040195111003957

Ferriz, H., Mahood, G. A., 1984. Eruption rates and compositional trends at Los Humeros Volcanic Center, Puebla, Mexico. Journal of Geophysical Research: Solid Earth 89 (B10), 8511-8524, doi: 10.1029/JB089iB10p08511. URL: http://onlinelibrary.wiley.com/doi/10.1029/ JB089iB10p08511/abstract

Ferriz, H., Mahood, G. A., 1987. Strong Compositional Zonation in a Silicic 
Magmatic System: Los Humeros, Mexican Neovolcanic Belt. Journal of Petrology 28 (1), 171-209, doi: 10.1093/petrology/28.1.171.

URL: https://academic .oup.com/petrology/article/28/1/171/ 1494706/Strong-Compositional-Zonation-in-a-Silicic

Fitz-Díaz, E., Lawton, T. F., Juárez-Arriaga, E., Chávez-Cabello, G., 2017. The Cretaceous-Paleogene Mexican orogen: Structure, basin development, magmatism and tectonics. Earth-Science ReviewsDoi: 10.1016/j.earscirev.2017.03.002.

URL: http://www.sciencedirect.com/science/article/pii/ S0012825217301204

Gutiérrez-Negrín, L.C.A., Izquierdo-Montalvo, G., 2010. Review and update of the main features of the Los Humeros Geothermal Field, Mexico. Proceedings World Geothermal Congress, Bali, Indonesia, 7.

Gómez-Tuena, A., Carrasco-Núñez, G., 2000. Cerro Grande volcano: the evolution of a Miocene stratocone in the early Trans-Mexican Volcanic Belt. Tectonophysics 318 (1), 249-280, doi: 10.1016/S0040-1951(99)00314-5.

URL: http://www.sciencedirect.com/science/article/pii/ S0040195199003145

Le Maitre, R.W., Bateman, P., Dudek, A., Keller, J., Lameyre, J., Le Bas, M.J., Sabine, P.A., Schmid, R., Sorensen, H., Streckeisen, A., Zanettin, B., 1989. A Classification of Igneous Rocks and Glossary of Terms. Blackwell, Oxford, 193.

López-Hernández, A., 1995. Estudio Regional Volcánico y Estructural del Campo Geotérmico de Los Humeros, Puebla., México. Geotermia, Revista Mexicana de Geoenergía 11 (1), 17-36.

López-Ramos, E., 1979. Geología de México, II, 454.

Norini, G., Groppelli, G., Sulpizio, R., Carrasco-Núñez, G., Dávila-Harris, P., Pellicioli, C., Zucca, F., De Franco, R., 2015. Structural analysis and thermal remote sensing of the Los Humeros Volcanic Complex: Implications for volcano structure and geothermal exploration. Journal of Volcanology and Geothermal Research 301, 221-237, doi: 10.1016/j.jvolgeores.2015.05.014.
URL: http://www.sciencedirect.com/science/article/pii/ S0377027315001663

Pérez-Reynoso, J., 1978. Geología y petrografía de la caldera de Los Humeros. Geomimet 3, 97-106.

Riggs, N., Carrasco-Núñez, G., 2004. Evolution of a complex isolated dome system, Cerro Pizarro, central México. Bulletin of Volcanology 66 (4), 322-335, doi: 10.1007/s00445-003-0313-y.

URL: https://link.springer.com/article/10.1007/ s00445-003-0313-y

Rojas Ortega, E., 2016. Litoestratigrafía, petrografía y geoquímica de la toba Llano, y su relación con el cráter el Xalapazco, Caldera de Los Humeros, Puebla.

URL: https://colecciondigital.cemiegeo.org/xmlui/handle/ $123456789 / 509$

Stuiver, M., Reimer, P.J., and Reimer, R.W., 2017. CALIB 7.1 [WWW program] at http://calib.org.

Viniegra-Osorio, F., 1965. Geología del Macizo de Teziutlán y la Cuenca Cenozoica de Veracruz. Boletín de la Asociación Mexicana de Geólogos Petroleros 17, 101-163.

Willcox, C. P., 2012. Eruptive, magmatic and structural evolution of a large explosive caldera volcano, Los Humeros, Central Mexico.

URL: http://hdl .handle.net/2381/10159

Yáñez, C., and García, S., 1982. Exploración de la región geotérmica Los Humeros-Las Derrumbadas, Estados de Puebla y Veracruz. Comisión Federal de Electricidad, 96Internal Report.

This article accompanies the following material:

HTML:

DOI: 10.22201/igg.terradigitalis.2017.2.24.76

Static map:

DOI: 10.22201/igg.terradigitalis.2017.2.24.81

Supplementary Material: DOI: 10.22201/igg.terradigitalis.2017.2.24.79 